ISSN : 2615-1995, E-ISSN : 2615-0654

J. Madani., Vol. 1, No. 2, September 2018 (363-381)

(C)2018 Lembaga Kajian Demokrasi

MADANI

dan Pemberdayaan Masyarakat (LKD-PM)

\title{
PENGARUH ORIENTASI PASAR DAN INOVASI PRODUK UNTUK MENINGKATKAN KINERJA PEMASARAN (STUDI KASUS PADA PT. BISMA NARENDRA DI JAKARTA)
}

\author{
Jasmani \\ Fakultas Ekonomi, Universitas Pamulang \\ djasmany@yahoo.com
}

\begin{abstract}
Abstrak
Penelitian ini bertujuan untuk mengetahui pengaruh orientasi pasar dan inovasi produk untuk meningkatkan kinerja pemasaran pada PT. Bisma Narendra di Jakarta. Metode yang digunakan adalah explanatory research, dan pengujian hipotesis. Dengan teknik survei, menyebar kuesioner dengan skala Likert. Teknik penentuan memakai sampling jenuh dengan 60 responden. Teknik analisis data yang digunakan analisis deskriptif dan analisis statistik inferesial yaitu: 1.Uji Validitas dan Reliabilitas, 2. Uji Asumsi Klasik, 3.Analisis Regresi Berganda, 4.Analisis Koefisien Korelasi, 5.Analisis Koefisien Determinasi (R2), 6. Pengujian Hipotesis dengan Uji Parsial (uji t) dan Uji Simultan (uji F). Hasil Pengujian dan analisisnya adalah sebagai berikut :

1. Terdapat pengaruh positif dan signifikan antara orientasi pasar terhadap kinerja pemasaran, dengan korelasi positif 0,639 dan kontribusi pengaruh sebesar 40,8\%. Uji hipotesis diperoleh nilai $t_{\text {hitung }}$ sebesar 6,324 dengan signifikansi t sebesar 0,000.

2. Terdapat pengaruh positif dan signifikan antara inovasi produk terhadap kinerja pemasaran, dengan korelasi positif 0,579 dan kontribusi pengaruh sebesar 33,5\%. Uji hipotesis diperoleh nilai $t_{\text {hitung }}$ sebesar 5,405 dengan signifikansi t sebesar 0,000.

3. Terdapat pengaruh positif dan signifikan antara orientasi pasar dan inovasi produk secara simultan terhadap kinerja pemasaran dengan korelasi positif 0,689 dan mempunyai kontribusi pengaruh sebesar 47,5\% dan sisanya sebesar 52,5\% dipengaruhi faktor lain yang tidak diteliti. Uji hipotesis diperoleh nilai $F_{\text {hitung }}$ sebesar 25,746 dengan signifikan $F$ sebesar 0,000.
\end{abstract}

Kata Kunci : Orientasi Pasar, Inovasi Produk dan Kinerja Pemasaran

\section{PENDAHULUAN \\ Latar Belakang}

Perkembangan bisnis di Indonesia dan dipasar internasional semakin mengalami peningkatan yang cukup tinggi sehingga persaingan sesama pelaku industri semakin tajam terlebih kemajuan teknologi juga semakin berinovasi menyesuaikan tingkat kebutuhan pasar dengan menghadirkan berbagai kecanggihannya. Sebuah perusahaan harus dapat menangkap peluang teknologi tersbut dengan mem- pergunakan sebagai bagian dari alat strategi dalam pemasarannya.

Tidak dapat dipungkiri bahwa dengan semakin meningkatnya persaingan dalam memperoleh pasar maupun merebut pasar sasaran dari pasar competitor tidaklah mudah. Oleh karenanya perusahaan harus secara tepat dapat menetapkan strategi dalam rangka memasarkan produk maupun jasanya. Apabila sebuah perusahaan tidak mampu untuk mengoptimalkan penjualan atas produk dan jasa- 
nya maka jelas akan menurunkan hasil penjualan yang diperoleh bahkan jika hal tersebut berlangsung secara terus menerus bukan tidak mungkin perusahaan akan mengalami kebangkrutan.

Menurut Ferdinand (2000) berpendapat bahwa "Jika perusahaan tidak mampu untuk bertahan dalam sebuah persaingan, maka dapat dipastikan perusahaan tersebut akan mengalami kerugian dalam market sharenya". Perusahaan didalam upaya menjaga market share yang telah diperoleh dan mempertahankannya, perusahaan juga harus mampu merencanakan dan menerapkan berbagai strategi yang diarahkan untuk membangun sebuah keunggulan dalam bersaing sehingga dapat memenangkan pasar persaingan dengan sempurna. Agar semua strategi yang dibuat dapat meningkatkan kinerja pemasaran maka strategi perusahaan harus selalu diarahkan untuk menghasilkan kinerja, baik kinerja keuangan maupun pemasaran.

Menurut Paul (1982) menjelaskan bahwa "Strategi-strategi yang efektif dapat melihat dalam tempat-tempat yang paling berkembang melalui sarana dalam upaya untuk mencapai tujuan dalam pemasaran". Menurut pendapat Fandy Tjiptono (2013) "Pemasaran harus mampu mempertimbangkan fokus jangka panjang secara bertahap agar mampu meningkatkan kinerja dan peningkatan daya saing perusahaan melalui kebutuhan pasar dengan mengimplementasikan konsep pemasaran". Dalam sebuah perusahaan faktor kualitas produk menjadi penting diperhatikan mengingat penerimaan konsumen mencerminkan diterima atau tidak produk tersebut tentu berdasar pada tingkat kebutuhan yang diinginkannya.

PT. Bisma Narendra sebagai salah satu pelaku industri baja galvanis penting untuk memanfaatkan kesempatan yang saat ini semakin terbuka secara lua. Tidak hanya mencoba untuk bertahan dengan varian produk yang sekarang ini ada, namun juga harus dimiliki variasi produk lainnya guna mempertahankan pasar yang sudah dimilikinya namun juga membuat inovasi produk dengan berbahan baja dengan produk yang lebih bervariasi sesuai dengan kebutuhan dan keinginan pasar. Disektor industri perumahan sekarang ini menjadi salah satu contoh peluang bagi pelaku industri manufacturer di Indonesia. Banyaknya bahan kayu yang diganti dengan baja galvanis seperti trust, genteng, kerangka mebel dan lainnya. Menurut Fandy Tjiptono (2013) "Orientasi pasar juga merupakan determinan kinerja pemasaran yang lebih penting dalam kondisi pasar yang turbulen, sangat kompetitif dan memiliki tingkat penggunaan teknologi yang relatif stabil". Dalam pemasaran, orientasi pasar diyakini memiliki kekuatan yang besar untuk mempengaruhi seseorang untuk membeli produk yang dijualnya.

Dengan demikian, di dalam orientasi pasar dan kemampuan perusahaan dalam berinovasi atau memiliki rancangan varian produk yang terbarukan jika dilihat dari kinerja pemasaran dalam bentuk yang sama tetapi dalam sistem yang berbeda maka akan menghasilkan kinerja pemasaran yang berbeda juga.

Mengingat bahwa orientasi pasar dan inovasi produk merupakan salah satu faktor penting yang dapat meningkatkan kinerja pemasaran, maka penulis tertarik untuk melakukan penelitian lebih dalam dengan judul : "Pengaruh Orientasi Pasar Untuk Meningkatkan Kinerja Pemasaran Pada PT. Bisma Narendra Di Jakarta”.

\section{Pembatasan Masalah}

Dengan keterbatasan peneliti serta agar lebih mudah di pahami dan dimengerti maka penelitian ini penulis memberikan batasanbatasan yang diteliti, yaitu mengenai orientasi pasar dan inovasi produk dan pengaruhnya terhadap kinerja pemasaran pada PT. Bisma Narendra Jakarta, dengan cara melakukan penyebaran kuesioner kepada pelanggan perusahaan yang membeli produk pada periode tertentu di PT. Bisma Narendra Jakarta.

\section{Perumusan Masalah}

Berdasarkan identifikasi dan pembatasan masalah di atas, maka untuk mencegah terjadinya kerancuan dalam pembahasan, perlu penulis berikan suatu perumusan masalah sebagai berikut :

1. Bagaimana pengaruh secara parsial antara orientasi pasar terhadap kinerja pemasaran pada PT. Bisma Narendra di Jakarta?

2. Bagaimana pengaruh secara parsial antara inovasi produk terhadap kinerja pemasaran pada PT. Bisma Narendra di Jakarta?

3. Bagaimana pengaruh secara simultan anta- 
ra orientasi pasar dan inovasi produk terhadap kinerja pemasaran pada PT. Bisma Narendra di Jakarta?

\section{Tujuan Penelitian}

Tujuan penelitian ini adalah :

1. Untuk mengetahui seberapa besar pengaruh secara parsial antara orientasi pasar terhadap kinerja pemasaran pada PT. Bisma Narendra di Jakarta .

2. Untuk mengetahui seberapa besar pengaruh secara parsial antara inovasi produk terhadap kinerja pemasaran pada PT. Bisma Narendra di Jakarta.

3. Untuk mengetahui seberapa besar pengaruh secara simultan antara orientasi pasar dan inovasi produk terhadap kinerja pemasaran pada PT. Bisma Narendra di Jakarta.

\section{TINJAUAN TEORITIK}

\section{Manajemen Manajemen}

Menurut Hasibuan (2016) berpendapat bahwa "Manajemen adalah ilmu dan seni mengatur proses pemanfaatan sumber daya manusia dan sumber-sumber lainnya secara efektif dan efisien untuk mencapai tujuan tertentu". Sedangkan menurut Samsudin Salidi (2010) berpendapat bahwa "Manajemen didefinisikan sebagai bekerja dengan orang-orang untuk mencapai tujuan organisasi dengan pelaksanaan fungsi-fungsi perencanaan (planning), pengorganisasian (organizing), penyusunan personalia atau kepegawaian (staffing), pengarahan dan kepemimpinan (leading) dan pengawasan (controlling)".

Dari beberapa pendapat di atas, maka disimpulkan bahwa manajemen merupakan kemampuan atau keterampilan untuk memperoleh suatu hasil yang maksimal dalam rangka pencapaian tujuan organisasi yang telah ditentukan sebelumnya dengan menggunakan sumber daya yang dimilikinya.

\section{Manajemen Pemasaran}

Menurut Sofjan Assauri (2013) berpendapat "Manajemen pemasaran merupakan kegiatan penganalisaan, perencanaan, pelaksanaan dan pengendalian program-program yang dibuat untuk membentuk, membangun dan memelihara keuntungan dari pertukaran melalui sasaran pasar guna mencapai tujuan organisasi (perusahaan) dalam jangka panjang". Sedangkan menurut Kotler (2014) menyampaikan bahwa "Manajemen pemasaran merupakan proses perencanaan dan pelaksanaan, pemikiran, penetapan harga, promosi serta penyaluran gagasan dan jasa untuk menciptakan pertukaran yang memenuhi sasaran-sasaran individu dalam organisasi".

Lain halnya dengan pendapat Basu Swastha (2010) mendefinisikan "Manajemen pemasaran adalah suatu sistem keseluruhan dan kegiatan-kegiatan bisnis yang ditujukan untuk merencanakan, menentukan harga, mempromosikan dan mendistribusikan barang dan jasa yang memuaskan kebutuhan baik kepada pembeli yang ada maupun pembeli potensial".

Kesimpulan yang dapat ditarik dari pengertian-pengertian di atas yaitu manajemen pemasaran merupakan kegiatan bisnis yang dilakukan oleh individu maupun kelompok untuk memenuhi kebutuhan dan keinginan konsumen dan masyarakat. Pemasaran melibatkan keseluruhan orang sebagai sumber daya manusia didalam perusahaan untuk secara bersama-sama menciptakan dan mempertahankan pelanggan yang sudah ada sehingga orientasi ini semakin dapat disadari sebagai salah satu kunci dalam upaya meningkatkan tercapainya tujuan perusahaan.

\section{Pemasaran}

Pemasaran dalam suatu perusahaan memegang peranan yang sangat penting, karena merupakan salah satu kegiatan yang dilakukan untuk mempertahankan kelangsungan hidup operasional perusahaan, melakukan perkembangan terhadap perusahaan dan untuk pencapaian tujuan perusahaan dalam memperoleh laba atau profit yang diinginkan.

Menurut Kotler (2014) mendefinisikan "Pemasaran adalah suatu proses dimana perusahaan menciptakan nilai bagi pelanggan dan membangun hubungan yang kuat dengan pelanggan dengan tujuan menangkap nilai dari pelanggan sebagai imbalannya". Sedangkan menurut Hasan (2013) "Pemasaran adalah proses mengidentifikasi, menciptakan dan mengkomunikasikan nilai, serta memelihara hubungan yang memuaskan pelanggan untuk memaksimalkan keuntungan perusahaan.

Lain halnya dengan Jhon W. Mullins \& Orville C. Walker. Jr (2013) yang mendefinisikan 
"Pemasaran adalah suatu proses social yang melibatkan kegiatan yang diperlukan mengaktifkan individu dan organisasi untuk mendapatkan apa yang mereka butuhkan dan inginkan melalui bertukar dengan lainnya dan mengembangkan hubungan yang berkelanjutan".

Dari beberapa definisi tersebut di atas, maka disimpulkan bahwa pemasaran adalah suatu proses sosial atau fungsi organisasi dalam sebuah kegiatan bisnis yang memiliki tujuan menyalurkan atau mendistribusikan barang dalam rangka memenuhi dan memuaskan kebutuhan pelanggan.

\section{Orientasi Pasar}

Orientasi pasar merupakan budaya bisnis dimana perusahaan memiliki komitmen untuk terus melakukan kreativitas dalam menciptakan keunggulan bagi pelanggannya. Menurut Uncles (2005) mendefinisikan bahwa "Orientasi pasar merupakan suatu proses dan aktivitas yang berhubungan dengan penciptaan dan pemuasan pelanggan dengan cara terus menilai kebutuhan dan keinginan pelanggan".

Lain halnya dengan pendapat Adi Sismanto (2006) yang mendefinisikan "Orientasi pasar merupakan sebuah filosofi bisnis dan perilaku dalam mengelola sebuah bisnis". Sedangkan Martin (2004) berpendapat bahwa "Dalam perusahaan yang menjalankan orientasi pasar, akan selalu berupaya untuk mengembangkan sistem manajemen kinerja dalam mengelola informasi pasar yang akan membangun komitmen pada seluruh bagian perusahaan dalam melayani pelanggan".

Menurut Narver dan Alster (2007) berpendapat bahwa "Orientasi pasar sebagai budaya organisasi yang paling efektif dalam menciptakan perilaku penting untuk penciptaan nilai unggul bagi pembeli serta kinerja dalam sebuah bisnis". Adapun indikator yang dipakai dalam orientasi pasar terdiri dari tiga indikator, yaitu:

a. Orientasi pelanggan yaitu kemampuan perusahaan untuk memahami para pelanggannya.

b. Orientasi pesaing yaitu kemampuan perusahaan dalam memonitori para pesaingnya.

c. Informasi pasar yaitu kemampuan perusahaan dalam menyediakan informasi mengenai produk yang dihasilkan.

\section{Inovasi Produk}

Inovasi produk dalam pemasaran merupakan tahapan yang harus diperhatikan dalam menganalisis hidup matinya sebuah produk (Product life circle). Inovasi dipandang sebagai salah satu penentu dalam kinerja sebuah perusahaan, terlebih saat ini cara pemasar dalam memasarkan produk dan jasanya sudah semakin canggih dengan hadirnya teknologi dengan berbagai kemampuan penggunaan dan memiliki implikasi pada bagaimana pelanggan akan memilih suatu produk tertentu. Kemampuan inovasi suatu perusahaan mencerminkan kemampuan perusahaan agar tetap dapat survive dan bersaing ditengah persaingan industri yang semakin ketat. Dalam konteks itulah perusahaan harus memiliki pandangan maupun kebijakan bahwa inovasi produk merupakan suatu keharusan.

Menurut Adelina, et.al, (2016) menyampaikan bahwa "Perusahaan harus melihat inovasi sebagai ide baru yang dapat menciptakan nilai tambah bagi perusahaan". Sedangkan menurut (Hurley dan Hult, 1998 dalam (Wahyono, 2002) mendefinisikan bahwa "Inovasi adalah satu aspek penentu terhadap kinerja perusahaan, dalam lingkungan persaingan yang semakin ketat. Kemampuan inovasi suatu perusahaan akan menjamin kemampuan bersaing perusahaan".

Dengan demikian suatu perusahaan sudah semestinya harus memandang bahwa inovasi sebagai suatu ide yang baru yang dapat menciptakan nilai tambah atau benefit bagi kelangsungan hidup perusahaan. Pendapat Freeman (2004) menganggap bahwa "Inovasi sebagai upaya dari perusahaan melalui penggunaan teknologi dan informasi untuk mengembangkan, memproduksi dan memasarkan produk yang baru untuk industri". Dengan kata lain inovasi merupakan modifikasi atau penemuan ide untuk perbaikan secara terus-menerus serta pengembangan untuk memenuhi kebutuhan pelanggan. Adapun elemen-elemen yang menjadi indikator dalam mengukur inovasi produk terdiri atas:

a. Kultur inovasi yaitu budaya organisasi yang ada dalam perusahaan untuk selalu menciptakan produk-produk baru.

b. Inovasi teknis yaitu inovasi pada proses 
perusahaan dalam menghasilkan produk baru.

c. Inovasi administrasi dan layanan yaitu proses perbaikan pencatatan dan proses yang diberikan perusahaan dalam melayani konsumen atau pelanggannya.

\section{Kinerja Pemasaran}

Kinerja pemasaran merupakan tolok ukur keberhasilan sebuah perusahaan dalam memenangkan sebuah pasar bisnis. Menurut pendapat Sampurno (2010) mengatakan bahwa "Kinerja pemasaran merupakan akumulasi dari hasil akhir atas seluruh aktivitas dan proses kerja dari perusahaan atau suatu tampilan keadaan secara menyeluruh atas perusahaan selama periode waktu tertentu, yang merupakan hasil atau prestasi yang dipengaruhi oleh kegiatan operasional perusahaan dalam memanfaatkan sumber-sumber daya yang dimilikinya”. Sedangkan menurut Pramono dan Waridin (2006) menyampaikan bahwa "Kinerja pemasaran merupakan ukuran prestasi yang diperoleh dari aktifitas proses pemasaran secara menyeluruh dari sebuah perusahaan atau organisasi. Kinerja pemasaran juga dipandang sebagai sebuah konsep yang digunakan untuk mengukur sampai sejauh mana prestasi pasar yang telah dicapai oleh suatu produk yang dihasilkan perusahaan".

Lain halnya menurut pendapat Permadi (2011) menyampaikan bahwa "Kinerja pemasaran merupakan konsep untuk mengukur prestasipemasaransuatuproduk. Kualitaskinerja pemasaran yang ditunjang oleh pemahaman terhadap konsumen dan keunggulan produk yang baru merupakan faktor-faktor yang dapat meningkatkan kesuksesan produk baru yang berhubungan dengan penciptaan superior value bagi konsumen. Terciptanya superior value bagi konsumen merupakan batu loncatan bagi suatu perusahaan untuk meningkatkan kinerja dalam pemasarannya”.

Menurut Prasetya (2002) berpendapat bahwa "Kinerja pemasaran dapat diukur dengan menggunakan berbagai kriteria alat ukur pengukurannya. Jika menggunakan penggukuran dengan kriteria tunggal maka tidak akan mampu memberikan pemahaman yang komperhensif tentang bagaimana kinerja suatu perusahaan itu sesengguhnya".

Adapun terkait dengan kinerja pemasaran, menurut Voss dan Voss (2000) membagi menjadi elemen-elemen yang menjadi indikator dalam mengukur kinerja pemasaran terdiri atas:

a. Volume penjualan yaitu volume atau jumlah produk yang berhasil dicapai oleh perusahaan.

b. Pangsa Pasar yaitu bagian pasar yang dikuasai oleh suatu perusahaan dan seluruh potensi jual.

c. Pertumbuhan pelanggan perusahaan yaitu tingkat pertumbuhan pelanggan yang berhasil dicapai oleh suatu perusahaan.

\section{Hipotesis Penelitian}

Hipotesis menurut Sugiyono (2014) adalah jawaban sementara terhadap rumusan masalah. Karena sifatnya masih sementara, maka perlu dibuktikan kebenarannya melalui data empirik yang terkumpul.

Adapun Hipotesis yang penulis ajukan adalah sebagai berikut:

H1 : Diduga terdapat pengaruh positif dan signifikan antara orientasi pasar terhadap kinerja pemasaran pada PT. Bisma Narendra di Jakarta.

H2 : Diduga terdapat pengaruh positif dan signifikan antara inovasi produk terhadap kinerja pemasaran pada PT. Bisma Narendra di Jakarta.

H3 : Diduga terdapat pengaruh positif dan signifikan antara orientasi pasar dan inovasi produk secara bersama-sama terhadap kinerja pemasaran pada PT. Bisma Narendra di Jakarta.

\section{METODOLOGI PENELITIAN}

\section{Tempat Dan Waktu Penelitian}

Penulis mengadakan penelitian pada PT. Bisma Narendra dengan alamat kantor pusat management dan marketing di Jalan Jend. Gatot Subroto Kav. 22 Jakarta.

\section{Populasi dan Sampel \\ Populasi}

Populasi penelitian merupakan sekumpulan objek yang ditentukan melalui suatu kriteria tertentu yang akan dikategorikan ke dalam objek yang akan diteliti. Menurut Sugiyono (2014) mendefinisikan "Populasi adalah jumlah wilayah generalisasi yang terdiri atas 
obyek atau subyek yang mempunyai kualitas dan karakteristik yang ditetapkan oleh peneliti dan kemudian ditarik kesimpulannya. Adapun populasi dalam penelitian ini adalah pelanggan perusahaan yang melakukan order pembelian pada PT.Bisma Narendra di Jakarta pada setiap bulannya.

\section{Sampel}

Menurut Sugiyono (2014) yaitu "Sampel adalah jumlah dan karakteristik yang dimiliki oleh populasi tersebut". Sedangkan menurut Suharsini Arikunto (2010), berpendapat bahwa "Sampel adalah sebagian atau wakil populasi yang diteliti”.

Dalam pengambilan sampel dapat menggunakan sampling jenuh dimana menurut Sugiyono (2014) berpendapat "Sampling jenuh adalah teknik penentuan sampel bila semua anggota populasi digunakan sebagai sampel". Istilah lain sampel jenuh adalah sensus, dimana anggota populasi di jadikan sebagai sampel. Dengan demikian sampel dalam penelitian ini adalah teknik sampling jenuh yaitu orang yang mewakili perusahaannya yang menjadi pelanggan PT. Bisma Narendra, dalam hal ini berjumlah 60 orang.

\section{Variabel Penelitian}

Dalam penelitian ini terdapat tiga variabel, yaitu variabel independen, variabel dependen dan variabel moderating, seperti berikut :

1. Variabel bebas (independent variable) Variabel bebas yang dalam hubungannya dengan variabel lain bertindak sebagai penyebab atau yang mempengaruhi variabel dependen. Pada penelitian ini sebagai variabel independen yakni orientasi pasar dan inovasi produk. Variabel independen sering disebut sebagai predictor yang dilambangkan dengan $\mathrm{X}$.

2. Variabel terikat (dependent variable) Variabel yang tergantung dengan variabel lain, atau variabel yang dapat dipengaruhi oleh variabel lain. Sering disebut variabel respon di mana dalam penelitian ini adalah kinerja pemasaran yang dilambangkan dengan Y.

\section{Definisi Operasional Variabel}

Pengertian operasional variabel ini kemudian diuraikan menjadi indikator empiris yang meliputi :
1. Orientasi Pasar $\left(\mathrm{X}_{1}\right)$

Variabel ini diukur melalui indikator: Kultur inovasi, Inovasi teknis, dan Inovasi administrasi

2. Inovasi Produk $\left(\mathrm{X}_{2}\right)$ Variabel ini diukur melalui indikator: Kultur inovasi, Inovasi teknis, dan Inovasi administrasi

3. Kinerja pemasaran $(\mathrm{Y})$

Variabel ini diukur melalui indikator: Volume penjualan, Pertumbuhan pelanggan perusahaan, dan Kemampuan laba yaitu besarnya keuntungan yang diperoleh perushaaan.

\section{METODE PENGUMPULAN DATA}

\section{Kuesioner}

Dalam penelitian ini untuk mendapatkan data primer kuantitatif, penulis menghubungi responden yaitu pelanggan yang merupakan pelanggan yang secara rutin membeli produk di PT. Bisma Narendra Jakarta.

\section{Wawancara}

Dalam penelitian ini untuk mendapatkan data primer kualitatif dengan metode wawancara, penulis datang ke kantor maupun pabrik PT. Bisma Narendra Jakarta untuk melakukan studi pendahuluan dengan teknik wawancara langsung dengan pihak yang berkompeten dalam perusahaan, mengenai obyek yang diteliti.

\section{Studi Pustaka}

Untuk medapatkan data sekunder penulis melakukan dengan cara penelaahan terhadap literature-literature berupa buku-buku kuliah dan data yang diperoleh dalam bentuk yang sudah jadi, sudah diolah oleh pihak lain biasanya dalam bentuk publikasi serta bahanbahan yang berhubungan dengan masalah yang berkaitan dengan penelitian ini.

\section{Metode Analisis Data}

Metode analisis data yang digunakan dalam penelitan ini adalah:

\section{Uji Instrumen}

\section{a. Uji Validitas}

Valid adalah menunjukkan derajad ketepatan antara data yang sesungguhnya terjadi pada obyek dengan data yang dapat di- 
kumpulkan oleh peneliti. Menurut Sugiyono (2014) "Valid berarti terdapat kesamaan antara data yang terkumpul dengan data yang sesungguhnya”.

Menurut Ghozali (2013) berpendapat "Suatu kuesioner dikatakan valid jika pertanyaan pada kuesioner mampu untuk mengungkapkan sesuatu yang akan diukur oleh kuesioner tersebut". Untuk melakukan uji validitas dilihat dari tabel Item-Total Statistics. Nilai tersebut dibandingkan dengan standar Chronbatch Alpha 0,30.

Kriteria atau syarat ketentuan keputusan suatu instrumen dikatakan valid dan tidaknya menurut Ghozali (2013) yaitu dengan membandingkan antara $\mathrm{r}_{\text {hitung }}$ (chronbatch Alpha) dengan 0,30 dengan ketentuan :

1). Jika chronbatch Alpha $>0,30$, maka instrumen valid.

2). Jika chronbatch Alpha $<0,30$, maka instrumen tidak valid.

\section{b. Uji Reliabilitas}

Model analisis uji reliabiltas yang digunakan dalam penelitian ini adalah model Alpha Cronbach. Menurut Ghozali (2013) "Reliabilitas merupakan alat untuk menguji kekonsistenan jawaban responden atas pertanyaan di kuesioner. Suatu kuesioner dikatakan reliabel jika jawaban seseorang terhadap pertanyaan adalah konsisten atau stabil dari waktu ke waktu".

Kriteria yang digunakan apabila suatu alat ukur memberikan hasil yang stabil, maka disebut alat ukur itu handal. Hasil ukur itu diterjemahkan dengan koefisien keandalan yaitu derajat kemampuan alat ukur mengukur perbedaan-perbedaan individu yang ada. Keandalan itu perlu, sebab data yang tidak andal atau bias tidak dapat diolah lebih lanjut karena akan menghasilkan kesimpulan yang bias. Pengukuran dilakukan sekali dan reliabilitas dengan uji statistik Cronbach Alpha ( $\alpha$ ).

Dalam pengukurannya one shot akan dilakukan dengan analisis Cronbach's Alpha. Ghozali (2013) mengklasifikasikan nilai Cronbach's Alpha sebagai berikut:

1). Nilai Cronbach's Alpha antara 0,00-0,20 dikatakan kurang reliabel;

2). Nilai Cronbach's Alpha antara 0,21 - 0,40 dikatakan agak reliabel;

3). Nilai Cronbach's Alpha antara 0,41 - 0,60 dikatakan cukup reliabel;
4). Nilai Cronbach's Alpha antara 0,61 - 0,80 dikategorikan reliabel;

5). Nilai Cronbach's Alpha antara 0,81 - 1,00 dikatakan sangat reliabel.

\section{Uji Asumsi Klasik}

Uji asumsi klasik digunakan untuk mengetahui ketepatan sebuah data. Menurut Singgih Santoso (2011) "Sebuah model regresi akan digunakan untuk melakukan peramalan, sebuah model yang baik adalah model dengan kesalahan peramalan yang seminimal mungkin. Karena itu, sebuah model sebelum digunakan seharusnya memenuhi beberapa asumsi, yang biasa disebut asumsi klasik". Dalam penelitian ini uji asumsi klasik yang digunakan adalah meliputi: Uji Normalitas, Uji Multikolinearitas, Uji Autokorelasi, dan Uji Heterokedastisitas.

\section{a. Uji Normalitas}

Uji normalitas digunakan untuk menguji apakah dalam sebuah model regresi, variabel dependen, variabel independen, atau keduanya mempunyai distribusi normal atau tidak. Menurut Ghozali (2013) berpendapat "Model regresi yang baik adalah berdistribusi normal atau mendekati normal". Jadi uji normalitas bukan dilakukan pada masing-masing variabel tetapi pada nilai residualnya. Dengan demikian uji ini untuk memeriksa apakah data yang berasal dari populasi terdistribusi normal atau tidak. Uji normalitas dapat berpedoman pada uji Kolmogorov Smirnov dengan ketentuan sebagai berikut :

1). Jika nilai signifikansi $<0,05$ (taraf kepercayaan $95 \%$ ), maka data tidak berdistribusi normal.

2). Jika nilai signifikansi $>0,05$ (taraf kepercayaan $95 \%$ ), maka data berdistribusi normal.

\section{b. Uji Multikolinieritas}

Uji Multikoliniearitas ini bertujuan menguji apakah pada model regresi ditemukan adanya korelasi antar variabel independen. Menurut Ghozali (2013), berpendapat bahwa "Uji multikolinearitas bertujuan untuk menguji apakah pada model regresi ditemukan adanya korelasi antar variabel bebas (independen)". Model regresi yang baik seharusnya tidak terjadi korelasi di antara variabel independen. Jika variabel independen saling berkorelasi, maka variabel-variabel ini tidak ortogonal. Variabel 
ortogonal adalah variabel independen yang nilai korelasi antar sesama variabel independen sama dengan nol.

Untuk mendeteksi ada tidaknya multikoliniearitas dalam model regresi dapat dilihat dari tolerance value atau Variance Inflation Factor (VIF) dengan ketentuan sebagai berikut:

1) Jika nilai nilai tolerance lebih $>$ dari 0.1 dan nilai Variance Inflation Factor (VIF) < dari 10 , maka tidak terjadi multikolinieritas.

2) Jika nilai nilai tolerance lebih $<$ dari 0.1 dan nilai Variance Inflation Factor (VIF) $>$ dari 10, maka terjadi multikolinieritas.

\section{c. Uji Autokorelasi}

Uji autokorelasi digunakan untuk mengetahui ada atau tidaknya penyimpangan asumsi klasik autokorelasi, yaitu adanya korelasi antar anggota sampel. Menurut Ghozali (2013) Uji autokorelasi bertujuan menguji apakah dalam model regresi liner ada korelasi antar kesalahan pengganggu pada periode $t$ dengan kesalahan pengganggu pada periode $\mathrm{t}-1$.

Autokorelasi muncul karena observasi yang berurutan sepanjang waktu berkaitan satu sama lainnya. Masalah ini timbul karena residual tidak bebas dari satu observasi ke observasi lainnya. Model regresi yang baik adalah regresi yang bebas dari autokorelasi. Cara yang dapat digunakan untuk menditeksi ada atau tidaknya autokorelasi dalam penelitian ini yaitu dengan uji Durbin-Watson (DW test) dengan berpedoman pada kriteria pedoman sebagai berikut:

\begin{tabular}{|c|c|}
\hline \multicolumn{2}{|c|}{ Tabel 1. Pedoman Uji Autokorelasi } \\
Dengan Memakai Uji Durbin-Watson (DW test) \\
\hline$<1,000$ & Ada autokorelasi \\
\hline $1,100-1,540$ & Tanpa kesimpulan \\
\hline $1,550-2,460$ & Tidak ada autokorelasi \\
\hline $2,460-2,900$ & Tanpa kesimpulan \\
\hline$>2,900$ & Ada autokorelasi \\
\hline & Sumber : Algifari, (2011:88). \\
\hline
\end{tabular}

\section{d. Uji Heteroskesdastisitas}

Menurut Ghozali (2013) "Uji heteroskedastisitas bertujuan untuk mengetahui apakah dalam model regresi terjadi ketidaksamaan varian dari suatu residual pengamatan ke pengamatan lain". Untuk mengetahui ada tidaknya heteroskedastisitas adalah dengan menggunakan uji Glejser.
Ketentuan dalam uji Glejser dapat melihat hasil uji nilai residual absolut diregresi dengan variabel independen. Adapun ketentuannya terjadi dan tidak terjadi gangguan heteroskedastisitas adalah sebagai berikut :

1). Jika variabel independen signifikan secara statistik atau memiliki nilai signifikansi (Sig.) $<0,05$, maka terjadi gangguan heteroskedastisitas.

2). Jika variabel independen tidak signifikan secara statistik atau memiliki nilai signifikansi (Sig.) $>0,05$, maka terjadi gangguan heteroskedastisitas.

\section{Analisis Deskriptif dan Verifikatif}

a. Analisis Deskriptif

Analisis dilakukan dengan melihat frekuensi dari pilihan opsi oleh responden yang disediakan pada setiap pertanyaan kuesioner yang diberikan. Dalam penelitian ini, untuk pembobotan data, peneliti menggunakan skala pengukuran. Menurut Sugiyono (2014), skala pengukuran merupakan kesepakatan yang digunakan sebagai acuan untuk menentukan panjang pendeknya interval yang ada dalam alat ukur sehingga alat ukur tersebut bila digunakan dalam pengukuran akan menghasilkan data. Adapun skala pengukuran yang digunakan dalam penelitian ini adalah dengan skala Likert.

\section{b. Analisis Verivikatif}

Analisis kuatitatif merupakan penelitian untuk menilai kondisi dari nilai pengaruh dan signifikansi pengaruh tersebut. Menurut Sugiyono (2014) “Metode verifikatif merupakan penelitian yang bertujuan untuk mengetahui hubungan antara 2 (dua) variabel atau lebih". Dengan demikian dari hasil dari analisis ini akan memberikan jawaban awal dari rumusan masalah mengenai pengaruh variabel independen terhadap variabel dependen. Adapun tahapan analisis yang dilakukan meliputi:

\section{1) Analisis Regresi Lnier Sederhana}

Analisis regresi liner sederhana ini dalam penelitian ini dimaksudkan untuk menganalisis pengaruh secara parsial antara variabel orientasi pasar $\left(\mathrm{X}_{1}\right)$ dan inovasi produk $\left(\mathrm{X}_{2}\right)$ terhadap kinerja pemasaran $(\mathrm{Y})$.

2) Analisis Regresi Berganda

Di mana untuk mencapai tujuan penelitian yaitu menganalisis pengaruh 
orientasi pasar $\left(\mathrm{X}_{1}\right)$ dan inovasi produk $\left(\mathrm{X}_{2}\right)$ secara bersama-sama terhadap kinerja pemasaran (Y) adalah dengan menggunakan analisis regresi berganda (Multiple regresional analisis).

3) Analisis Koefisien Korelasi

Analisis ini bertujuan untuk mengetahui tingkat keterhubungan atau pengaruh masing-masing variabel independen terhadap variabel dependennya. Dalam hal ini adalah orientasi pasar $\left(\mathrm{X}_{1}\right)$ dan inovasi produk $\left(\mathrm{X}_{2}\right)$ terhadap kinerja pemasaran $(\mathrm{Y})$ baik secara parsial maupun secara simultan.

4) Analisis Koefisien Korelasi

Dalam penelitian ini untuk mengetahui berapa besar prosentase kontribusi dari variabel orientasi pasar dan inovasi produk terhadap kinerja pemasaran pada PT. Bisma Narendra di Jakarta baik secara parsial maupun secara simultan.

5) Pengujian Hipotesis

Pengujian hipotesis dimaksudkan untuk menguji dugaan sementara yang dirumuskan dalam hipotesis berdasarkan data empiris. Dalam penelitian ini pengujian hipotesis dilakukan dengan uji t dan uji $\mathrm{F}$.

(a) Uji t (Parsial)

Uji t digunakan untuk menguji signifikansi variasi hubungan antar variabel $\mathrm{X}$ dan $\mathrm{Y}$, apakah variabel $\mathrm{X}_{1}$ dan $\mathrm{X}_{2}$ benar-benar berpengaruh secara parsial terhadap variabel dependen.

(b) Uji F (Simultan)

Pengujian hipotesis simultan (Uji F) bertujuan untuk mengetahui pengaruh secara bersama-sama variabel independen terhadap variabel dependen.

\section{ANALISIS DAN PEMBAHASAN \\ Analisis Deskriptif Variabel Penelitian}

Sesuai dengan tujuan analisis deskriptif yaitu untuk memberikan gambaran mengenai hasil penelitian secara umum, bagaimana karakteristik subyek penelitian sehubungan dengan variabel-variabel yang diteliti. Sebelum dilakukan analisis statistik terlebih dahulu dilakukan pembobotan terhadap skor masing- masing variabel. Pembobotan dilakukan dengan memberikan skor total dengan jumlah item dari variabel yang dibobot, melalui pertanyaaan yang diberikan penulis dalam kuesioner dapat di deskriptifkan setiap variabel yang diteliti.

Metode yang diambil dalam penelitian ini adalah metode pengukuran Likert. Dimana pertanyaan mengandung lima alternatif jawaban. Dan bentuk pertanyaan telah disusun menggunakan pengukuran Likert yang diberi bobot sebagai berikut:

\begin{tabular}{|c|c|}
\hline \multicolumn{2}{|c|}{ Tabel 2. Skala Likert } \\
\hline Jawaban & Bobot \\
\hline Sangat Setuju (SS) & 5 \\
\hline Setuju (S) & 4 \\
\hline Kurang Setuju (KS) & 3 \\
\hline Tidak Setuju (TS) & 2 \\
\hline Sangat Tidak Setuju (STS) & 1 \\
\hline
\end{tabular}

$$
P=\frac{\text { RANGE }}{\text { KELAS }}=\frac{5-1}{5}=0,8
$$

Maka dapat ditetapkan interval sebagai berikut :

\begin{tabular}{|c|c|}
\hline \multicolumn{2}{|c|}{ Tabel 2 Rentang Skala } \\
\hline Nilai Rata-rata & Bobot \\
\hline $1,00-1,79$ & Sangat Tidak Setuju (STS) \\
\hline $1,80-2,59$ & Tidak Setuju (TS) \\
\hline $2,60-3,39$ & Kurang Setuju (KS) \\
\hline $3,40-4,19$ & Setuju (S) \\
\hline $4,20-5,00$ & Sangat Setuju (SS) \\
\hline & Sumber : Sugiyono (2014) \\
\hline
\end{tabular}

\section{Variabel Orientasi Pasar $\left(X_{1}\right)$}

Orientasi pasar merupakan upaya dalam mengembangkan sebuah sistem manajemen kinerja dimana didalamnya terdapat bagaimana mengelola informasi pasar sehingga akan membangun komitmen pada keseluruhan yang menjadi bagian dari perusahaan terkait upaya melayani pelanggan dengan sebaik-baiknya. Adapun dalam variabel ini diukur melalui indikator: a) Orientasi pelanggan, b) Orientasi pesaing, c) Informasi pasar. Adapun penilaian responden atas orientasi pasar yang dilakukan PT. Bisma Narendr dapat di paparkan sebagai berikut : 


\begin{tabular}{|c|c|c|c|c|c|c|c|c|c|}
\hline \multicolumn{10}{|c|}{ Tabel 3. Variabel Orientasi Pasar $\left(X_{1}\right)$} \\
\hline \multirow{2}{*}{ No } & \multirow{2}{*}{ Pernyataan } & STS & TS & KS & $\mathbf{s}$ & SS & \multirow{2}{*}{ Total } & \multirow{2}{*}{ Rata-rata } & \multirow{2}{*}{ Ket. } \\
\hline & & (1) & (2) & (3) & (4) & (5) & & & \\
\hline 1 & Komitmen memuaskan pelanggan & 0 & 2 & 19 & 27 & 12 & 60 & 3.82 & $\mathrm{~S}$ \\
\hline 2 & Memahami keluhan pelanggan & 0 & 2 & 18 & 30 & 10 & 60 & 3.80 & $S$ \\
\hline 3 & Ketepatan menangani komplain & 0 & 2 & 20 & 30 & 8 & 60 & 3.73 & S \\
\hline 4 & Memberikan solusi yang terbaik & 1 & 2 & 17 & 24 & 16 & 60 & 3.87 & $S$ \\
\hline 5 & Penggunaan strategi pasar & 0 & 1 & 16 & 28 & 15 & 60 & 3.95 & S \\
\hline 6 & Pesaing sebagai acuan pasar & 0 & 1 & 17 & 32 & 10 & 60 & 3.85 & $S$ \\
\hline 7 & Mendesain persaingan kompetitif & 0 & 2 & 17 & 29 & 12 & 60 & 3.85 & $\mathrm{~s}$ \\
\hline 8 & Produk memiliki ciri yang khas & 0 & 1 & 17 & 28 & 14 & 60 & 3.92 & $S$ \\
\hline 9 & 9 Menyediakan informasi produk & 0 & 1 & 19 & 28 & 12 & 60 & 3.85 & $S$ \\
\hline 10 & Melakukan promosi ke luar & 0 & 1 & 26 & 24 & 9 & 60 & 3.68 & $S$ \\
\hline 11 & Membuat program discount harga & 1 & 1 & 11 & 30 & 17 & 60 & 4.02 & $S$ \\
\hline \multirow[t]{2}{*}{12} & Mengenal harga pasar & 0 & 1 & 13 & 33 & 13 & 60 & 3.97 & $S$ \\
\hline & \multicolumn{7}{|c|}{ Rata-rata Variabel Orientasi pasar } & 3.86 & $S$ \\
\hline \multicolumn{10}{|c|}{ Sumber: Data primer diolal } \\
\hline
\end{tabular}

Bila dilihat dari tabel diatas rata-rata skor variabel orientasi pasar sebesar 3,85 masuk pada interval 3,40-4,19 atau dengan interprestasi setuju yang artinya responden mempunyai persepsi bahwa dalam memenuhi produknya, perusahaan memiliki konsep yang berorientasi pada pemenuhan kebutuhan pelanggan, memberikan harga yang bersaing dan memberikan informasi pasar yang terkini.

\section{Variabel Inovasi Produk $\left(\mathrm{X}_{2}\right)$}

Inovasi produk merupakan upaya perusahaan dalam memberikan pilihan pada pelanggan atas produk yang dibelinya, berdasar pada keunggulan dan variasi produk yang disediakan oleh perusahaan. Variabel ini diukur melalui indikator: a) Kultur inovasi, b) Inovasi teknis, dan c) Inovasi administrasi dan layanan. Adapun penilaian responden atas inovasi produk yang dilaksanakan pada PT. Bisma Narendra dapat di paparkan sebagai berikut:

\begin{tabular}{|c|c|c|c|c|c|c|c|c|c|}
\hline \multicolumn{10}{|c|}{ Tabel 4. Variabel Inovasi Produk $\left(\mathrm{X}_{2}\right)$} \\
\hline \multirow{2}{*}{ No } & \multirow{2}{*}{ Pernyataan } & STS & TS & KS & $\mathbf{s}$ & SS & \multirow{2}{*}{ Total } & \multirow{2}{*}{ Rata-rata } & \multirow{2}{*}{ Ket. } \\
\hline & & (1) & (2) & (3) & (4) & (5) & & & \\
\hline 1 & Komitmen untuk update produk & 0 & 1 & 16 & 33 & 10 & 60 & 3.87 & $S$ \\
\hline 2 & Desain produk yang lebih menarik & 0 & 0 & 23 & 24 & 13 & 60 & 3.83 & $S$ \\
\hline 3 & Ketahanan produk yang lebih kuat & 0 & 1 & 22 & 24 & 13 & 60 & 3.82 & S \\
\hline 4 & Produk mudah dibentuk & 0 & 3 & 16 & 26 & 15 & 60 & 3.88 & $\mathrm{~s}$ \\
\hline 5 & Proses produksi yang efektif & 0 & 2 & 26 & 22 & 10 & 60 & 3.67 & $\mathrm{~S}$ \\
\hline 6 & Penyelesaian produk yang tepat & 0 & 0 & 15 & 34 & 11 & 60 & 3.93 & $S$ \\
\hline 7 & Kualitas proses produksi & 0 & 0 & 23 & 24 & 13 & 60 & 3.83 & S \\
\hline 8 & Produk memiliki nilai yang tinggi & 0 & 0 & 24 & 25 & 11 & 60 & 3.78 & S \\
\hline 9 & Melakukan perbaikan administrasi & 0 & 4 & 19 & 26 & 11 & 60 & 3.73 & S \\
\hline 10 & Concern pelayanan pelanggan & 0 & 1 & 20 & 30 & 9 & 60 & 3.78 & $S$ \\
\hline 11 & Pemberian garansi pada produk & 0 & 1 & 23 & 25 & 11 & 60 & 3.77 & $S$ \\
\hline \multirow[t]{2}{*}{12} & Pengantaran produk tanpa biaya tambahan & 0 & 0 & 12 & 23 & 25 & 60 & 4.22 & S \\
\hline & \multicolumn{7}{|c|}{ Rata-rata Variabel Orientasi Pasar } & 3.85 & S \\
\hline \multicolumn{10}{|c|}{ Sumber: Data primer diolat } \\
\hline
\end{tabular}

Bila dilihat dari tabel diatas rata-rata skor variabel kinerja pemasaran sebesar 3,85 masuk pada interval 3,40-4,19 atau dengan interpretasi setuju yang artinya responden mempunyai persepsi bahwa perusahaan memiliki kemampuan yang baik dalam hal menciptakan inovasi 
produk yang mampu memenuhi harapan dan kebutuhan pelanggannya.

\section{Variabel Kinerja Pemasaran (Y)}

Kinerja pemasaran merupakan perkembangan dan hasil yang dicapai dalam memasarkan sebuah produk maupun jasa. Variabel ini diukur melalui indikator: a) Volume penjualan, b) Pangsa Pasar, dan c) Pertumbuhan pelanggan perusahaan. Adapun penilaian responden atas kinerja pemasaran yang dilaksanakan pada PT. Bisma Narendra dapat di paparkan sebagai berikut:

\begin{tabular}{|c|c|c|c|c|c|c|c|c|c|}
\hline \multirow{2}{*}{ No } & \multirow{2}{*}{ Pernyataan } & STS & TS & KS & $\mathbf{s}$ & SS & \multirow{2}{*}{ Total } & \multirow{2}{*}{ Rata-rata } & \multirow{2}{*}{ Ket. } \\
\hline & & (1) & (2) & (3) & (4) & (5) & & & \\
\hline 1 & Tercapainya target penjualan & 0 & 0 & 14 & 37 & 9 & 60 & 3.92 & $S$ \\
\hline 2 & Pertumbuhan penjualan & 0 & 1 & 17 & 28 & 14 & 60 & 3.92 & $S$ \\
\hline 3 & Tercapainya target penjualan & 0 & 1 & 22 & 28 & 9 & 60 & 3.75 & $S$ \\
\hline 4 & Pemenuhan produk yang baik & 0 & 1 & 10 & 32 & 17 & 60 & 4.08 & $S$ \\
\hline 5 & Segmen dan sasaran penjualan & 0 & 2 & 26 & 22 & 10 & 60 & 3.67 & $S$ \\
\hline 6 & Perluasan pasar sasaran & 0 & 0 & 18 & 34 & 8 & 60 & 3.83 & $S$ \\
\hline 7 & Tingkat penerimaan produk & 0 & 1 & 12 & 29 & 18 & 60 & 4.07 & $S$ \\
\hline 8 & Penanganan komplain yang baik & 0 & 0 & 21 & 24 & 15 & 60 & 3.90 & $S$ \\
\hline 9 & Pertumbuhan pelanggan & 0 & 0 & 18 & 32 & 10 & 60 & 3.87 & $S$ \\
\hline 10 & Penambahan pelanggan baru & 0 & 0 & 15 & 33 & 12 & 60 & 3.95 & $S$ \\
\hline 11 & Kepuasan pelanggan & 0 & 0 & 15 & 30 & 15 & 60 & 4.00 & $S$ \\
\hline \multirow[t]{2}{*}{12} & Profitabilitas perusahaan & 0 & 0 & 15 & 30 & 15 & 60 & 4.00 & $S$ \\
\hline & \multicolumn{7}{|c|}{ Rata-rata Variabel Orientasi pasar } & 3.92 & $S$ \\
\hline \multicolumn{10}{|c|}{ Sumber: Data primer diola } \\
\hline
\end{tabular}

Bila dilihat dari tabel diatas rata-rata skor variabel kinerja pemasaran sebesar 3,92 masuk pada interval 3,40-4,19 atau dengan interpretasi setuju yang artinya responden mempunyai persepsi bahwa perusahaan memiliki kemampuan yang baik dalam hal upaya-upaya menciptakan strategi pemasaran yang lebih mengedepankan kebutuhan pasar sehingga mampu mendatangkan keuntungan yang diharapkan.

\section{Pengujian Instrumen Data}

\section{Hasil Uji Valiiditas}

Berdasar perhitungan dengan menggunakan menggunakan Software IBM SPSS (Statistical Program for Social Science) versi 24.00 for windows. Seluruh butir pernyataan yang digunakan dalam penelitian diperoleh nilai Chronbatch Alpha $>0.30$ dan nilai r positif, dengan demikian maka semua butir pernyataan dikatakan valid.

\section{Hasil Uji Reliabilitas}

Berdasar perhitungan dengan menggunakan menggunakan Software IBM SPSS (Statis- tical Program for Social Science) versi 24.00 for windows. Diperoleh nilai Cronbach Alfa lebih besar dari 0.60 dan nilai $r$ bernilai positif, dengan demikian maka butir pernyataan dalam variabel dalam penelitian dikatakan reliabel dan data layak untuk diolah ke pengujian berikutnya.

\section{Pengujian Asumsi Klasik}

\section{Uji Normalitas}

Uji normalitas dilakukan untuk menguji apakah dalam model regresi, variabel dependen dan variabel independen berdistribusi normal atau berdistribusi tidak normal. Berikut ini Hasil uji normalitas dengan alat uji KolmogorovSmirnov Test, sebagai berikut:

\begin{tabular}{|l|r|r|r|r|r|r|}
\hline \multicolumn{1}{|c|}{ Tabel 6. Hasil Normalitas Dengan Kolmogorov-Smirnov Test } \\
\hline \multirow{2}{*}{$\begin{array}{l}\text { Kolmogorov- } \\
\text { Smirnov }\end{array}$} & \multicolumn{3}{|c|}{ Shapiro-Wilk } \\
\cline { 2 - 7 } & Statistic & df & Sig. & Statistic & df & Sig. \\
\hline $\begin{array}{l}\text { Kepuasan } \\
\text { Pelanggan }(Y)\end{array}$ & .094 & 60 & $.200^{*}$ & .969 & 60 & .131 \\
\hline
\end{tabular}


Berdasarkan hasil pengujian pada tabel di atas, diperoleh nilai signifikansi $\alpha=0,200$ dimana nilai tersebut lebih besar dari nilai a $=0,050$ atau $(0,200>0,05)$. Dengan demikian maka asumsi distribusi persamaan pada uji ini adalah normal.

\section{Uji Multikonilieritas}

Pengujian mutlikolinearitas dilakukan untuk meyakini bahwa antar variabel bebas tidak memiliki multikolinearitas atau tidak memiliki hubungan korelasi antara variabel yang ditetapkan sebagai model dalam penelitian, karena model regresi yang baik seharusnya tidak terjadi korelasi di antara variabel independen. Uji multikolinearitas dilakukan dengan melihat nilai Tolerance Value dan Variance Inflation Factor (VIF). Adapun hasil pengujiannya sebagai berikut:

\begin{tabular}{|l|r|r|}
\hline \multirow{2}{*}{\multicolumn{1}{|c|}{ Tabel 7. Hasil Uji Multikolinieritas }} & \multicolumn{2}{c|}{ Dengan Collinierity Statistic } \\
\cline { 2 - 3 } & \multicolumn{2}{c|}{ Collinearity Statistics } \\
\hline 1 (Constant) & & \multicolumn{1}{c|}{ VIF } \\
\hline Kualitas Produk $\left(\mathrm{X}_{1}\right)$ & .668 & 1.496 \\
\hline Kualitas Pelayanan $\left(\mathrm{X}_{2}\right)$ & .668 & 1.496 \\
\hline \multicolumn{3}{|c|}{ Sumber : Data primer diolah. } \\
\hline
\end{tabular}

Berdasarkan hasil pengujian pada tabel di atas, nilai tolerance masing-masing variabel bebas yaitu $0,668<1,0$ dan nilai Variance Inflation Factor (VIF) sebesar 1,496 < 10, dengan demikian model regresi ini tidak ada multikolinearitas.

\section{Uji Autokorelasi}

Pengujian Autokorelasi digunakan untuk mengetahui ada atau tidaknya penyimpangan korelasi antar anggota sampel. Pengujian dilakukan dengan alat uji Darbin-Watson (DW test). Adapun hasil pengujiannya sebagai berikut:

\begin{tabular}{|l|r|r|r|r|r|}
\hline \multicolumn{7}{|c|}{ Tabel 8. Hasil Uji Autokorelasi } \\
\hline Model & \multicolumn{1}{|c|}{$\mathbf{R}$} & R Square & $\begin{array}{c}\text { Adjusted R } \\
\text { Square }\end{array}$ & $\begin{array}{c}\text { Std. Error of } \\
\text { the Estimate }\end{array}$ & $\begin{array}{r}\text { Durbin- } \\
\text { Watson }\end{array}$ \\
\hline 1 & $.689^{\mathrm{a}}$ & .475 & .456 & 3.136 & 2.080 \\
\hline \multicolumn{7}{|c|}{ Sumber : Data primer diolah. } \\
\hline
\end{tabular}

Berdasarkan hasil pengujian pada tabel di atas, model regresi ini tidak ada autokorelasi, hal ini dibuktikan dengan nilai Durbin-Watson sebesar 2.080 yang berada diantara interval $1.550-2.460$

\section{Uji Heteroskesdastisitas}

Pengujian heteroskedastisitas dimaksudkan untuk menguji apakah dalam sebuah model regresi terjadi ketidaksamaan varians residual. Salah satu cara untuk mendeteksi ada tidaknya heteroskedastisitas adalah dengan uji Glejser. Adapun hasil pengujiannya sebagai berikut:

\begin{tabular}{|c|c|c|c|c|c|}
\hline \multicolumn{6}{|c|}{ Coefficients $^{\mathrm{a}}$} \\
\hline \multirow[b]{2}{*}{ Model } & \multicolumn{2}{|c|}{$\begin{array}{l}\text { Unstandardized } \\
\text { Coefficients }\end{array}$} & \multicolumn{3}{|c|}{ Standardized Coefficients } \\
\hline & B & Std. Error & Beta & $t$ & Sig. \\
\hline 1 (Constant) & 4.075 & 2.543 & & 1.603 & .115 \\
\hline Orientasi Pasar $\left(X_{1}\right)$ & -.093 & .057 & -.256 & -1.618 & .111 \\
\hline Inovasi Produk $\left(X_{2}\right)$ & .058 & .062 & .149 & .937 & .353 \\
\hline \multicolumn{6}{|c|}{ a. Dependent Variable: RES2 } \\
\hline & & & \multicolumn{3}{|c|}{ Sumber : Data Primer diolah } \\
\hline
\end{tabular}

Berdasarkan hasil pengujian glejser test model pada tabel di atas, variabel orientasi pasar $\left(\mathrm{X}_{1}\right)$ diperoleh nilai prob. Sig. 0,111 dan inovasi produk (Sig.) 0,353 > 0,05. Dengan demikian regression model tidak ada gangguan heteroskesdastisitas.

\section{Hasil Analisis Data}

Pada bagian pengujian ini dimaksudkan untuk menunjukkan hasil dari pengujian atas variabel Orientasi pasar $\left(\mathrm{X}_{1}\right)$ dan Inovasi produk $\left(\mathrm{X}_{2}\right)$ Terhadap Kinerja pemasaran $(\mathrm{Y})$. Adapun hasil analisis dalam penelitian ini sebagai berikut:

\section{Analisis Regresi Linier Sederhan}

Uji regresilinier sederhanaini dimaksudkan untuk mengetahui seberapa besar pengaruh variabel orientasi pasar $\left(\mathrm{X}_{1}\right)$ dan inovasi produk $\left(\mathrm{X}_{2}\right)$ terhadap kinerja pemasaran $(\mathrm{Y})$ secara sendiri-sendiri. Adapun hasil analisis regresi linier sederhana sebagai berikut Berdasarkan perhitungan regresi berganda menggunakan program IBM SPSS (Statistical Program for Social Science) versi 24.00 for windows, diperoleh hasil sebagai berikut :

\begin{tabular}{|c|c|c|c|c|c|}
\hline \multicolumn{6}{|c|}{$\begin{array}{l}\text { Tabel 10. Hasil Uji Regresi Linier Sederhana Antara } \\
\text { Orientasi Pasar }\left(X_{Y}\right) \text { Terhadap Kinerja Pemasaran }(Y)\end{array}$} \\
\hline \multicolumn{6}{|c|}{ Coefficients $^{\mathrm{a}}$} \\
\hline \multirow[b]{2}{*}{ Model } & \multicolumn{2}{|c|}{$\begin{array}{l}\text { Unstandardized } \\
\text { Coefficients }\end{array}$} & \multicolumn{3}{|c|}{ Standardized Coefficients } \\
\hline & B & Std. Error & Beta & $t$ & Sig. \\
\hline 1 (Constant) & 22.271 & 3.925 & & 5.674 & .000 \\
\hline Orientasi Pasar $\left(X_{1}\right)$ & .533 & .084 & .639 & 6.324 & .000 \\
\hline
\end{tabular}


Dari hasil perhitungan pada tabel di atas dapat disajikan ke dalam bentuk persamaan regresi standardized: $\mathbf{Y}=\mathbf{2 2 , 2 7 1}+\mathbf{0 , 5 3 3 X _ { 1 }}$

Adapun persamaan tersebut dapat dijelaskan sebagai berikut :

a. Konstanta sebesar 22,271, menyatakan bahwa tanpa dipengaruhi variabel orientasi pasar maka besarnya nilai kinerja pemasaran sudah terbentuk sebesar 22,271.

b. Variabel orientasi pasar $\left(\mathrm{X}_{1}\right)$ berpengaruh positif terhadap kinerja pemasaran (Y) dengan nilai koefisien sebesar 0,533. Yang artinya jika variabel orientasi pasar $\left(\mathrm{X}_{1}\right)$ meningkat satu satuan dengan asumsi variabel lain tetap, maka kinerja pemasaran akan meningkat sebesar 0,533 satuan.

\begin{tabular}{|c|c|c|c|c|c|}
\hline \multicolumn{6}{|c|}{$\begin{array}{l}\text { Tabel 11. Hasil Uji Regresi Linier Sederhana Antara } \\
\text { Inovasi Produk }\left(X_{1}\right) \text { Terhadap Kinerja Pemasaran }(Y)\end{array}$} \\
\hline \multicolumn{6}{|c|}{ Coefficients ${ }^{\mathrm{a}}$} \\
\hline \multirow[b]{2}{*}{ Model } & \multicolumn{2}{|c|}{$\begin{array}{l}\text { Unstandardized } \\
\text { Coefficients }\end{array}$} & \multicolumn{3}{|c|}{ Standardized Coefficients } \\
\hline & B & Std. Error & Beta & $t$ & Sig. \\
\hline 1 (Constant) & 22.976 & 4.459 & & 5.153 & .000 \\
\hline Inovasi Produk $\left(X_{2}\right)$ & .520 & .096 & .579 & 5.405 & .000 \\
\hline
\end{tabular}

Dari hasil perhitungan pada tabel di atas dapat disajikan ke dalam bentuk persamaan regresi standardized: $\mathrm{Y}=\mathbf{2 2 , 9 7 6}+\mathbf{0 , 5 2 0} \mathrm{X}_{1}$.

Adapun persamaan tersebut dapat dijelaskan sebagai berikut :

a. Konstanta sebesar 22,976, menyatakan bahwa tanpa dipengaruhi variabel inovasi produk, maka besarnya nilai kinerja pemasaran sudah terbentuk sebesar 22,976.

b. Variabel inovasi produk $\left(\mathrm{X}_{2}\right)$ berpengaruh positif terhadap kinerja pemasaran (Y) dengan nilai koefisien sebesar 0,520. Yang artinya jika variabel inovasi produk $\left(\mathrm{X}_{2}\right)$ meningkat satu satuan dengan asumsi variabel lain tetap, maka kinerja pemasaran akan meningkat sebesar 0,520 satuan

\section{Analisis Regresi Berganda}

Analisis regresi berganda dimaksudkan untuk mengetahui seberapa besar pengaruh variabel orientasi pasar $\left(\mathrm{X}_{1}\right)$ dan inovasi produk $\left(\mathrm{X}_{2}\right)$ terhadap kinerja pemasaran $(\mathrm{Y})$. Berdasarkan perhitungan regresi berganda menggunakan program IBM SPSS (Statistical Program for Social Science) versi 22.00 for windows, diperoleh hasil sebagai berikut :

\begin{tabular}{|l|r|r|r|r|r|}
\hline \multicolumn{5}{|c|}{ Tabel 12. Hasil Uji Regresi Berganda } \\
\hline \multirow{2}{*}{ Coefficients } \\
\hline \multirow{2}{*}{ Model } & \multicolumn{1}{|c|}{$\begin{array}{c}\text { Unstandardized } \\
\text { Coefficients }\end{array}$} & \multicolumn{3}{|c|}{ Standardized Coefficients } \\
\cline { 2 - 7 } 1 (Constant) & \multicolumn{1}{c|}{ B } & \multicolumn{1}{c|}{ Std. Error } & Beta & \multicolumn{1}{c|}{ t } & Sig. \\
\hline Orientasi Pasar $\left(X_{1}\right)$ & 16.223 & 4.358 & & 3.723 & .000 \\
\hline Inovasi Produk $\left(X_{2}\right)$ & .381 & .098 & .457 & 3.893 & .000 \\
\hline & .283 & .105 & .315 & 2.686 & .009 \\
\hline
\end{tabular}

Berdasarkan hasil perhitungan pada tabel di atas dapat disajikan ke dalam bentuk persamaan regresi standardized sebagai berikut:

$$
Y=16,223+0,381 X_{1}+0,283 X_{2}
$$

Keterangan:

$\mathrm{Y}=$ Variabel Kinerja Pemasaran

$\mathrm{X}_{1}=$ Variabel Orientasi Pasar

$\mathrm{X}_{2}=$ Variabel Inovasi Produk

Adapun persamaan tersebut dapat dijelas-

kan sebagai berikut:

a. Constant value diperoleh sebesar 16,223, menyatakan bahwa tanpa dipengaruhi oleh variabel orientasi pasar dan inovasi produk besarnya nilai kinerja pemasaran sudah terbentuk sebesar 16,223 point.

b. Variabel orientasi pasar $\left(\mathrm{X}_{1}\right)$ berpengaruh positif dan signifikan terhadap kinerja pemasaran (Y) dengan nilai koefisien sebesar 0,381. Hal ini diartikan bahwa jika variabel orientasi pasar $\left(\mathrm{X}_{1}\right)$ meningkat satu satuan dengan asumsi variabel inovasi produk $\left(\mathrm{X}_{2}\right)$ tetap atau konstan (0), maka kinerja pemasaran (Y) juga akan mengalami peningkatan 0,381 satuan.

c. Variabel inovasi produk $\left(\mathrm{X}_{2}\right)$ berpengaruh positif dan signifikan terhadap kinerja pemasaran (Y) dengan nilai koefisien sebesar 0,283. Hal ini diartikan bahwa jika variabel inovasi produk $\left(\mathrm{X}_{2}\right)$ meningkat satu satuan dengan asumsi variabel orientasi pasar (X1) tetap atau konstan (0), maka kinerja pemasaran (Y) juga akan mengalami peningkatan sebesar $\mathbf{0 , 2 8 3}$ satuan.

\section{Analisis Koefisien Korelasi}

Analisis koefisien korelasi (R) digunakan untuk mengetahui tingkat kekuatan hubungan atau pengaruh dari variabel bebas terhadap variabel terikat, dalam hal ini adalah variabel orientasi pasar dan inovasi produk baik secara parsial maupun secara bersama-sama terhadap 
kinerja pemasaran. Adapun hasil pengolahan data dapat dijelaskan sebagai berikut :

\begin{tabular}{|l|l|r|r|}
\hline \multicolumn{4}{|c|}{$\begin{array}{c}\text { Tabel 13. Hasil Uji Koefisien Korelasi Pengaruh } \\
\text { Orientasi Pasar }\left(X_{1}\right) \text { Terhadap Kinerja Pemasaran }(Y)\end{array}$} \\
\hline \multicolumn{4}{|c|}{ Coefficients } \\
\hline \multirow{2}{*}{$\begin{array}{l}\text { Orientasi Pasar } \\
\left(X_{1}\right)\end{array}$} & Pearson Correlation & 1 & \multicolumn{1}{|c|}{ ROA $(Y)$} \\
\cline { 2 - 4 } & Sig. (2-tailed) & & $.639^{* *}$ \\
\hline $\begin{array}{l}\text { Kinerja } \\
\text { Pemasarann }(Y)\end{array}$ & Pearson Correlation & $.639^{* *}$ & .000 \\
\cline { 2 - 4 } & Sig. (2-tailed) & .000 & 1 \\
\hline \multicolumn{3}{|c|}{ Sumber : Data primer diolah } \\
\hline
\end{tabular}

Berdasarkan hasil pada tabel di atas diperoleh nilai korelasi sebesar 0,639. Hal ini menunjukkan bahwa variabel orientasi pasar $\left(\mathrm{X}_{1}\right)$ secara parsial memiliki tingkat hubungan yang kuat terhadap kinerja pemasaran $(\mathrm{Y})$.

\begin{tabular}{|c|c|c|c|}
\hline \multicolumn{4}{|c|}{$\begin{array}{l}\text { Tabel 14. Hasil Uji Koefisien Korelasi Pengaruh } \\
\text { Inovasi Produk }\left(\mathrm{X}_{2}\right) \text { Terhadap Kinerja Pemasaran }(\mathrm{Y})\end{array}$} \\
\hline \multicolumn{4}{|c|}{ Coefficients $^{\mathrm{a}}$} \\
\hline & & $\operatorname{CAR}\left(X_{1}\right)$ & ROA $(Y)$ \\
\hline \multirow{2}{*}{$\begin{array}{l}\text { Inovasi Produk } \\
\left(X_{2}\right)\end{array}$} & Pearson Correlation & 1 & $.579^{* *}$ \\
\hline & Sig. (2-tailed) & & .000 \\
\hline \multirow{2}{*}{$\begin{array}{l}\text { Kinerja } \\
\text { Pemasarann ( }(Y)\end{array}$} & Pearson Correlation & $.579^{* *}$ & 1 \\
\hline & Sig. (2-tailed) & .000 & \\
\hline \multicolumn{4}{|c|}{ Sumber : Data primer diolah } \\
\hline
\end{tabular}

Berdasarkan hasil pada tabel di atas diperoleh nilai korelasi sebesar 0,579 . Hal ini menunjukkan bahwa variabel inovasi produk $\left(\mathrm{X}_{2}\right)$ secara parsial memiliki tingkat hubungan yang sedang terhadap kinerja pemasaran $(\mathrm{Y})$.

\begin{tabular}{|c|r|r|r|r|}
\hline \multicolumn{6}{|c|}{$\begin{array}{c}\text { Tabel 15. Hasil Uji Koefisien Korelasi Pengaruh } \\
\text { Orientasi Pasar }\left(X_{1}\right) \text { dan Inovasi Produk }\left(X_{2}\right) \\
\text { secara simultan Terhadap Kinerja Pemasaran }(Y)\end{array}$} \\
\hline \multicolumn{6}{|c|}{ Model Summary } \\
\hline Model & R & R Square & Adjusted R Square & $\begin{array}{r}\text { Std. Error of } \\
\text { the Estimate }\end{array}$ \\
\hline 1 & .689 & .475 & .456 & 3.136 \\
\hline \multicolumn{7}{|c|}{} \\
\hline
\end{tabular}

Berdasarkan hasil pada tabel di atas diperoleh nilai korelasi sebesar 0,689. Hal ini menunjukkan bahwa variabel orientasi pasar $\left(\mathrm{X}_{1}\right)$ dan inovasi produk $\left(\mathrm{X}_{2}\right)$ secara simultan memiliki tingkat hubungan yang kuat terhadap kinerja pemasaran $(\mathrm{Y})$.

\section{Analisis Koefisien Determinasi}

Analisis koefisien deteminasi (Kd) digunakan untuk mengetahui kontribusi besarnya pengaruh antara variabel bebas terhadap variabel terikat, dalam hal ini adalah variabel orientasi pasar dan inovasi produk baik secara parsial maupun secara bersama-sama terhadap kinerja pemasaran. Adapun hasil pengolahan data dapat dijelaskan sebagai berikut :

\begin{tabular}{|l|r|r|r|r|}
\hline \multicolumn{5}{|c|}{$\begin{array}{c}\text { Tabel 16. Hasil Uji Koefisien Determinasi Pengaruh } \\
\text { Orientasi Pasar }\left(\mathrm{X}_{1}\right) \text { Terhadap Kinerja Pemasaran }(\mathrm{Y})\end{array}$} \\
\hline \multicolumn{6}{|c|}{ Model Summary } \\
\hline Model & R & R Square & Adjusted R Square & $\begin{array}{r}\text { Std. Error of } \\
\text { the Estimate }\end{array}$ \\
\hline 1 & $.639^{\circ}$ & .408 & .398 & 3.300 \\
\hline \multicolumn{6}{|c|}{ Sumber : Data primer diolah } \\
\hline
\end{tabular}

Berdasarkan hasil pada tabel di atas dapat dilihat bahwa nilai R Square sebesar 0,408 atau $40,8 \%$. Hal ini menunjukkan bahwa pengaruh orientasi pasar secara parsial terhadap kinerja pemasaran adalah sebesar $40,8 \%$, sedangkan sisanya sebesar 59,2,0\% dipengaruhi oleh faktor lain yang tidak diteliti.

\begin{tabular}{|l|r|r|r|r|}
\hline \multicolumn{5}{|c|}{$\begin{array}{c}\text { Tabel 17. Hasil Uji Determinasi Pengaruh } \\
\text { Inovasi Produk }\left(\mathrm{X}_{2}\right) \text { Terhadap Kinerja Pemasaran }(Y)\end{array}$} \\
\hline Model & \multicolumn{1}{|c|}{ R } & R Square & Adjusted R Square & $\begin{array}{r}\text { Std. Error of } \\
\text { the Estimate }\end{array}$ \\
\hline 1 & $.579^{\mathrm{a}}$ & .335 & .323 & 3.498 \\
\hline \multicolumn{6}{|c|}{ Sumber : Data primer diolah } \\
\hline
\end{tabular}

Berdasarkan hasil pada tabel di atas dapat dilihat bahwa nilai $R$ Square sebesar 0,335 atau $33,5 \%$. Hal ini menunjukkan bahwa pengaruh inovasi produk secara parsial terhadap kinerja pemasaran adalah sebesar $33,8 \%$, sedangkan sisanya sebesar $65,5 \%$ dipengaruhi oleh faktor lain yang tidak diteliti.

\begin{tabular}{|c|r|r|r|r|}
\hline $\begin{array}{r}\text { Tabel 18. Hasil Uji Koefisien Determinasi Pengaruh Orientasi Pasar } \\
\left(X_{1}\right) \text { dan Inovasi Produk }\left(X_{2}\right) \text { Terhadap Kinerja Pemasaran }(Y)\end{array}$ \\
\hline \multicolumn{5}{|c|}{ Model Summary } \\
\hline Model & R & R Square & Adjusted R Square & $\begin{array}{r}\text { Std. Error of } \\
\text { the Estimate }\end{array}$ \\
\hline 1 & $.689^{a}$ & .475 & .456 & 3.136 \\
\hline \multicolumn{4}{|c|}{ Sumber : Data primer diolah } \\
\hline
\end{tabular}

Berdasarkan hasil pada tabel di atas dapat dilihat bahwa nilai $R$ Square sebesar 0,475 atau 47,5\%. Hal ini menunjukkan bahwa pengaruh orientasi pasar $\left(\mathrm{X}_{1}\right)$ dan inovasi produk $\left(\mathrm{X}_{2}\right)$ secara bersama-sama terhadap kinerja pemasaran (Y) adalah sebesar 47,5\%, sedangkan sisanya sebesar $52,5 \%$ dipengaruhi oleh faktor lain yang tidak diteliti. 


\section{Pengujian Hipotesis}

Pengujian hipotesis dimaksudkan untuk menentukan apakah sebaiknya hipotesis diterima atau ditolak. Dalam pengujian ini digunakan uji t (parsial) dan uji F (Simultan).

a. Uji Hipotesis Parsial (Uji t)

Pengujian hipotesis secara parsial menggunakan uji t yaitu untuk menguji bagaimana pengaruh masing-masing variabel bebas secara sendiri-sendiri terhadap variabel terikatnya.

Hipotesis Pertama : Terdapat pengaruh positif dan signifikan antara orientasi pasar terhadap kinerja pemasaran pada PT. Bisma Narendra di Jakarta.

\begin{tabular}{|l|r|r|r|c|c|}
\hline \multicolumn{5}{|c|}{ Tabel 19. Pengujian Hipotesis Variabel } \\
Orientasi Pasar $\left(X_{1}\right)$ Terhadap Kinerja Pemasaran $(Y)$ \\
\hline \multirow{2}{*}{ Coefficients }
\end{tabular}

Berdasarkan hasil pengolahan data di atas, diperoleh nilai $\mathrm{t}_{\text {hitung }}>\mathrm{t}_{\text {tabel }}$ atau $(6,324>2,002)$, hal itu juga diperkuat dengan signifikansi 0,000 $<0,05$. Dengan demikian hipotesis pertama yang menyatakan terdapat pengaruh positif dan signifikan antara orientasi pasar terhadap kinerja pemasaran pada PT. Bisma Narendra di Jakarta dapat diterima.

Hipotesis Kedua : Terdapat pengaruh positif dan signifikan antara inovasi produk terhadap kinerja pemasaran pada PT. Bisma Narendra di Jakarta.

\begin{tabular}{|l|r|r|r|r|r|}
\hline \multicolumn{5}{|c|}{ Tabel 20. Pengujian Hipotesis Variabel } \\
Inovasi Produk $\left(\mathrm{X}_{2}\right)$ Terhadap Kinerja Pemasaran $(\mathrm{Y})$
\end{tabular}

Berdasarkan hasil pengolahan data di atas, diperoleh nilai $\mathrm{t}_{\text {hitung }}>\mathrm{t}_{\text {tabel }}$ atau $(5,405>2,002)$, hal itu juga diperkuat dengan nilai signifikansi $0,000<0,05$. Dengan demikian hipotesis kedua yang menyatakan terdapat pengaruh positif dan signifikan antara inovasi produk terhadap kinerja pemasaran pada PT. Bisma Narendra di Jakarta dapat diterima.

\section{b. Uji Hipotesis Secara Simultan (Uji F)}

Pengujian hipotesis secara simultan dimaksudkan untuk mengetahui pengaruh semua variabel bebas terhadap variabel terikat yaitu orientasi pasar dan inovasi produk terhadap kinerja pemasaran. Dalam pengujian ini digunakan uji $\mathrm{F}$.

Hipotesis Ketiga : Terdapat pengaruh positif dan signifikan antara orientasi pasar $\left(\mathrm{X}_{1}\right)$ dan inovasi produk $\left(\mathrm{X}_{2}\right)$ secara simultan terhadap kinerja pemasaran (Y) pada PT. Bisma Narendra di Jakarta.

Adapun hasil pengujiannya sebagai berikut:

\begin{tabular}{|l|l|r|r|r|c|c|}
\hline \multicolumn{7}{|c|}{ Tabel 21. Pengujian Hipotesis Secara Simultan } \\
\hline \multirow{2}{*}{ Model } & \multicolumn{1}{|c|}{$\begin{array}{c}\text { Sum of } \\
\text { Squares }\end{array}$} & df & $\begin{array}{c}\text { Mean } \\
\text { Square }\end{array}$ & F & Sig. \\
\hline \multirow{3}{*}{1} & Regression & 506.344 & 2 & 253.172 & 25.746 & $.000^{\mathrm{b}}$ \\
\cline { 2 - 8 } & Residual & 560.506 & 57 & 9.833 & & \\
\cline { 2 - 8 } & Total & 1066.850 & 59 & & & \\
\hline \multicolumn{7}{|c|}{ Sumber : Data primer diolah } \\
\hline
\end{tabular}

Berdasarkan hasil pengolahan data di atas, diperoleh nilai $\mathrm{F}_{\text {hitung }}>\mathrm{F}_{\text {tabel }}$ atau $(25,746>$ 2,770), dengan demikian hipotesis ketiga yang menyatakan terdapat pengaruh positif dan signifikan antara orientasi pasar dan inovasi produk secara simultan terhadap kinerja pemasaran pada PT. Bisma Narendra di Jakarta dapat diterima.

\section{PEMBAHASAN DAN HASIL}

Dari hasil pengujian statistik dan analisis diatas, maka dapat dipaparkan analisis pengaruh orientasi pasar dan inovasi produk terhadap kinerja pemasaran pada PT. Bisma Narendra di Jakarta, sebagai berikut :

\section{Pengaruh Orientasi Pasar Terhadap Kinerja Pemasaran Pada PT. Bisma Narendra di Jakarta.}

Dari hasil analisis statistik, diperoleh persamaan model regresi adalah $\mathrm{Y}=22,271$ $+0,533 \mathrm{X}_{1}$. Konstansta memiliki nilai positif sehingga apabila orientasi pasar mengalami kenaikan, maka kinerja pemasaran juga akan meningkat.

Koefisien korelasi antara orientasi pasar terhadap kinerja pemasaran adalah sebesar 
0,639. Dengan demikian dapat dikatakan bahwa kedua variabel memiliki hubungan yang positif sebesar 0,639 dengan tingkat hubungan atau pengaruh kuat.

Nilai koefisien determinasi diperoleh sebesar 0,408, data tersebut mengindikasikan bahwa variabel orientasi pasar memberikan kontribusi pengaruh sebesar $40,8 \%$ terhadap kinerja pemasaran pada PT. Bisma Narendra di Jakarta.

Uji hipotesis diperoleh nilai $\mathrm{t}_{\text {hitung }}>\mathrm{t}_{\text {tabel }}$ atau $(6,324>2,002)$ dan signifikansi $t<0,05$ atau $(0,000<0,05)$. Dengan demikian hipotesis $\mathrm{H} 1$ yang penulis ajukan dapat diterima, hal ini menunjukkan bahwa orientasi pasar berpengaruh positif dan siginifikan terhadap kinerja pemasaran pada PT. Bisma Narendra di Jakarta.

\section{Pengaruh Inovasi Produk Terhadap Kinerja Pemasaran Pada PT. Bisma Narendra di Jakarta}

Dari hasil analisis statistik, diperoleh persamaan model regresi adalah $\mathrm{Y}=22,976+$ $0,520 \mathrm{X}_{2}$. Konstansta memiliki nilai positif sehingga apabila inovasi produk mengalami kenaikan, maka kinerja pemasaran juga akan meningkat.

Koefisien korelasi antara inovasi produk terhadap kinerja pemasaran adalah sebesar 0,579. Dengan demikian dapat dikatakan bahwa kedua variabel memiliki hubungan yang positif sebesar 0,579 dengan tingkat hubungan atau pengaruh sedang.

Nilai koefisien determinasi diperoleh sebesar 0,335, data tersebut mengindikasikan bahwa variabel inovasi produk memberikan kontribusi pengaruh sebesar 33,5\% terhadap kinerja pemasaran pada PT. Bisma Narendra di Jakarta.

Uji hipotesis diperoleh nilai $\mathrm{t}_{\text {hitung }}>\mathrm{t}_{\text {tabel }}$ atau $(5,405>2,002)$ dan signifikansi $t<0,05$ atau $(0,000<0,05)$. Dengan demikian hipotesis $\mathrm{H}^{2}$ yang penulis ajukan dapat diterima, hal ini menunjukkan bahwa inovasi produk berpengaruh positif dan siginifikan terhadap kinerja pemasaran pada PT. Bisma Narendra di Jakarta.

3. Pengaruh Orientasi Pasar dan Inovasi Produk Secara Simultan Terhadap Kinerja Pemasaran Pada PT. Bisma

\section{Narendra di Jakarta.}

Dari hasil analisis statistik, diperoleh persamaan model regresi adalah $\mathrm{Y}=16,223+$ $0,381 \mathrm{X}_{1}+0,283 \mathrm{X}_{2}$. Konstansta memiliki nilai positif sehingga apabila orientasi pasar dan inovasi produk mengalami kenaikan, maka kinerja pemasaran juga akan meningkat.

Koefisien korelasi antara orientasi pasar dan inovasi produk secara simultan terhadap kinerja pemasaran adalah sebesar 0,689. Dengan demikian dapat dikatakan bahwa ketiga variabel memiliki hubungan yang positif sebesar 0,689 dengan tingkat hubungan atau pengaruh kuat.

Nilai koefisien determinasi diperoleh sebesar 0,475 , data tersebut mengindikasikan bahwa variabel orientasi pasar dan inovasi produk secara simultan memberikan kontribusi pengaruh sebesar $47,5 \%$ terhadap kinerja pemasaran pada PT. Bisma Narendra di Jakarta.

Uji hipotesis diperoleh nilai $\mathrm{F}_{\text {hitung }}>\mathrm{F}_{\text {tabel }}$ atau $(25,746>2,770)$ dan $\mathrm{F}$ signifikansi $<0,05$ atau $(0,000<0,05)$. Dengan demikian hipotesis $\mathrm{H} 3$ yang penulis ajukan dapat diterima, hal ini menunjukkan bahwa orientasi pasar dan inovasi produk secara simultan berpengaruh positif dan siginifikan terhadap kinerja pemasaran pada PT. Bisma Narendra di Jakarta.

\section{KESIMPULAN, IMPLIKASI DAN SARAN Kesimpulan}

Setelah penulis melakukan penelitian dan analisis mengenai pengaruh orientasi pasar dan inovasi produk terhadap kinerja pemasaran pada PT. Bisma Narendra di Jakarta, seperti yang telah dipaparkan pada bab-bab sebelumnya, maka penulis dapat menarik kesimpulan sebagai berikut:

1. Orientasi pasar berpengaruh positif dan siginifikan terhadap kinerja pemasaran pada PT. Bisma Narendra di Jakarta. Hal ini dapat dilihat dari Nilai $\mathrm{t}_{\text {hitung }}>\mathrm{t}_{\text {tabel }}$ $(6,324>2,002)$ dan signifikansi $t<0,05$ atau $(0,000<0,05)$ orientasi pasar mempunyai korelasi positif dengan kinerja pemasaran sebesar 0,639. Orientasi pasar mempunyai kontribusi pengaruh sebesar 40,8\% terhadap kinerja pemasaran. Model regresi sederhana yang diperoleh adalah $\mathrm{Y}=22,271+0,533 \mathrm{X}_{1}$ yang diartikan apabila orientasi pasar yang tinggi akan 
meningkatkan kinerja pemasaran pada PT. Bisma Narendra di Jakarta.

2. Inovasi produk berpengaruh positif dan siginifikan terhadap kinerja pemasaran pada PT. Bisma Narendra di Jakarta. Hal ini dapat dilihat dari Nilai $\mathrm{t}_{\text {hitung }}>\mathrm{t}_{\text {tabel }}$ atau $(5,405>2,002)$ dan signifikansi $t<$ 0,05 atau $(0,000<0,05)$ inovasi produk mempunyai korelasi positif dengan kinerja pemasaran sebesar 0,579. Inovasi produk mempunyai kontribusi pengaruh sebesar 33,5\% terhadap kinerja pemasaran. Model regresi sederhana yang diperoleh adalah $\mathrm{Y}$ $=22,976+0,520 \mathrm{X}_{2}$ yang diartikan apabila inovasi produk meningkat maka maka akan meningkatkan kinerja pemasaran pada PT. Bisma Narendra di Jakarta.

3. Orientasi pasar dan inovasi produk secara simultan berpengaruh positif dan siginifikan terhadap kinerja pemasaran pada PT. Bisma Narendra di Jakarta. Hal ini dapat dilihat dari Nilai $\mathrm{F}_{\text {hitung }}>\mathrm{F}_{\text {tabel }}$ atau $(25,746>2,770)$ dan $\mathrm{F}$ signifikansi $<0,05$ atau $(0,000<0,05)$. Orientasi pasar dan inovasi produk secara simultan mempunyai kontribusi $\left(\mathrm{R}^{2}\right)$ sebesar $47,5 \%$ terhadap kinerja pemasaran pada PT. Bisma Narendra di Jakarta, selebihnya sebesar $52,5 \%$ dipengaruhi oleh variabel lain yang tidak diteliti, misalnya kualitas produk, pelayanan, promosi dan lain-lain. Model regresi berganda yang diperoleh adalah $\mathrm{Y}=$ $16,223+0,381 \mathrm{X}_{1}+0,283 \mathrm{X}_{2}$ yang diartikan apabila orientasi pasar dan inovasi produk.

\section{Implikasi}

Dari hasil kesimpulan diatas, penelitian ini memiliki implikasi sebagai berikut :

1. Agar tingkat kinerja pemasaran pada PT. Bisma Narendra di Jakarta tetap tinggi maka hendaknya variabel orientasi pasar harus diperhatikan dan ditingkatkan oleh pihak PT. Bisma Narendra, indikatorindikator yang ada dalam orientasi pasar harus dipahami dan dijalankan oleh semua karyawan perusahaan, sehingga produk yang dihasilkan benar-benar dapat berorientasi kepada kebutuhan pasar dan dapat berkompetisi dengan baik.

2. Agar tingkat kinerja pemasaran pada PT. Bisma Narendra di Jakarta tetap tinggi maka hendaknya variabel inovasi produk harus diperhatikan dan ditingkatkan oleh pihak PT. Bisma Narendra, indikatorindikator yang ada dalam inovasi produk harus dipahami dan dijalankan oleh semua karyawan perusahaan. Inovasi produk apabila dapat dimaksimalkan dengan varian-varian yang baru dan inovatif serta dikelola dengan tepat maka akan memiliki kontribusi positif terhadap terwujudnya kinerja pemasaran yang positif.

3. Agar tingkat kinerja pemasaran pada PT. Bisma Narendra di Jakarta tetap tinggi maka hendaknya variabel dan indikatorindikator orientasi pasar dan inovasi produk secara bersama-sama dan terintegrasi harus diperhatikan dan ditingkatkan dan dipahami oleh pihak PT. Bisma Narendra, guna mendukung terciptanya proses pembelian pelanggan yang berkelanjutan, dapat menerapkan strategi pemasaran yang lain secara komprehensif dalam upaya menciptakan kinerja pemasaran, serta memperbaiki mutu produk agar memiliki kualitas yang lebih baik lagi yang pada akhirnya akan meningkatkan omzet perusahaan.

\section{Saran}

Berdasarkan kesimpulan di atas, maka penulis mengajukan beberapa saran yang diharapkan dapat bermanfaat bagi PT. Bisma Narendra. Adapun saran tersebut adalah sebagai berikut:

1. PT. Bisma Narendra harus meningkatkan usaha-usaha yang berkaitan dengan variabel orientasi pasar, memastikan kebijakankebijakan yang terkait dengan orientasi pasar dapat dijalankan oleh seluruh karyawan dengan baik dan menjaga kualitas produk sehingga mampu membuka pasar secra luas dan bersaing dengan produk kompetitor.

2. PT. Bisma Narendra harus meningkatkan upaya yang berkaitan dengan variabel inovasi produk dengan cara selalu melakukan analisis pasar terkait dengan produk baru yang seperti apa yang kedepan dibutuhkan oleh pasar sasaran dan invovasi dipandang sebagai keharusan dalam pemasaran karena tanpa inovasi maka produk yang lama lambat laun akan tidak diminati pasar. 
3. PT. Bisma Narendra harus meningkatkan usaha-usaha yang berkaitan dengan variabel kinerja pemasaran, memastikan kebijakankebijakan yang diambil seorang pemasar harus benar-benar mampu mendatangkan benefit baik untuk perusahaan maupun untuk customer.

4. Berdasarkan hasil penelitian bahwa kontribusi pengaruh variabel bebas terhadap variabel terikat adalah sebesar $47,5 \%$, nilai ini masih bisa ditingkatkan dengan secara perusahaan harus mampu menganalisis kebutuhan pasar dan konsumen akan trend produk ke depannya dan kondisi masing-masing variabel bebas harus ditingkatkan secara signifikan. Oleh karenanya disarankan kepada penelitian berikutnya agar melakukan penelitian yang relevan dengan cara memperbaiki indikator yang masih tidak baik atau dengan menambah indikator pertanyaan dan jumlah responden penelitian sehingga akan dapat lebih diketahui variabel yang paling memberikan kontribusi positif bagi perusahaan.

\section{DAFTAR PUSTAKA}

Arikunto, Suharsimi, (2010), "Prosedur Penelitian Suatu Pendekatan Praktek”, PT. Rineka Cipta. Jakarta.

Ferdinand A (2000), "Manajemen Pemasaran: "Sebuah Pendekatan Strategic", Research Paper Series, Progam Magister Manajemen Universitas Diponegoro, Semarang.

Uncles, M. (2005), "Market Orientation, Australia Journal of Management", Vol.5, No. 2, (September), pp. i-ix.

Samsudin, Sadili, (2010), "Manajemen Sumber Daya Manusia”, Pustaka Setia, Bandung.

Assauri Sofjan, (2013), "Manajemen Produksi dan Operasi". Edisi Revisi, Lembaga Penerbit Fakultas Ekonomi Universitas Indonesia, Jakarta.

Hasan, Ali. (2013), "Marketing dan Kasus-Kasus Pilihan". Yogyakarta: CAPS (Center For Academic Publising Service).

Hasibuan (2013), "Manajemen Sumber Daya Manusia", Cetakan Ketujuh, Belas, PT.Bumi Aksara, Jakarta.

Jhon W. Mullins \& Orville C. Walker. Jr (2013), "Marketing Management: A.Strategic
Decision-Making Approach", 8th Edition, McGraw Hill International Edition.

Narver, J.C. and Slater, SF, (1990), "The Effect of Market Orientation on Business Profitability, Jounal of Marketing", Vol.54, October, pp 20-35.

Adi Sismanto (2006), "Analisis Pengaruh Orientasi Pembelajaran, Orientasi Pasar dan Inovasi Terhadap Keunggulan Bersaing Untuk Meningkatkan Kinerja Pemasaran" Tesis. Universitas Diponegoro, Semarang.

Hurley,Robert F.and G.Thomas M.Hult (1998), "Innovation, Market Orientation, and Organizational Learning an Integration and Empirical Examination, Journal of Marketing",Vol. 62, (July 1998), pp. 42-54.

Freeman, R.E. (2004), "A Stakeholder Theory of Modern Corporations", Ethical Theory and Business, 7th ed.

Sampurno, (2010), "Manajemen Stratejik : Menciptakan Keunggulan Bersaing yang Berkelanjutan", Gadjah Mada University Press, Yogyakarta.

Pramono Sugeng dan Waridin (2006), "Pengaruh orientasi pasar, Promosi dan Inovasi Terhadap kinerja pemasaran Kredit (Studi Kasus pada Bank BRI Wil. Jawa Tengah)". Jurnal Ekonomi Bisnis.Vol. 7 No.1 Januari 2006: 17-32.

Voss, G.B., \& Voss Z.G. (2000), "Strategic Orientation and Firm Performance In an Artistic Enviroment", Journal of Marketing, Vol.64. p.67-83.

Algifari, (2010), "Analisis Regresi, Teori, Kasus dan Soluysi". Edisi kedua, BPFE UGM, Yogyakarta.

Alma, Buchori, (2009), "Manajemen Pemasaran \& Pemasaran Jasa", CV. Alfabetha. Bandung.

Arikunto, Suharsimi, (2010), "Prosedur Penelitian Suatu Pendekatan Praktek". PT. Rineka Cipta. Jakarta.

Assauri, Sofian, (2013), "Manajemen Produksi Dan Operasi”, LPFE Universitas Indonesia. Jakarta.

Durianto, D., Sugiarto, (2007), "Strategi Menaklukkan Pasar Melalui Riset Ekuitas dan Perilaku Merek", PT Gramedia Pustaka Utama. Jakarta.

G.R. Terry, \& Rue, Leslie W. Rue, (2010), "Dasardasar Manajemen", Bumi Aksara. Jakarta.

Ghozali, Imam, (2013), "Aplikasi Analisis 
Multivariate dengan Program SPSS", Edisi Kelima. Badan Penerbit Undip. Semarang. Hasan, Ali, (2013), "Marketing", Media Utama, Yogyakarta.

Hasibuan (2016), "Manajemen Sumber Daya Manusia", Haji Masagung. Jakarta.

Keller dan Amstrong. (2014), "Prinsip-prinsip Pemasaran", Edisi Kedua Belas. Jilid Satu. Erlangga. Jakarta.

Kotler, dan Keller, (2016), "Manajemen Pemasaran", PT Macaman Jaya Cemerlang. Jakarta.

Kotler, (2016), "Manajemen Pemasaran", Edisi Keempat belas, PT. Indeks, Jakarta.

Paul N, Bloom dan Louise (2006), "Strategi Pemasaran Produk", Prestasi Pustakarya, Jakarta.

Saladin, Djaslim. 2007. "Manajemen Pemasaran". PT. Linda Karya. Bandung.

Sarwono, Jonathan. 2012. "Metode Penelitian Kuantitatif dan Kualitatif". Graha Ilmu. Yogyakarta.

Simamora, Bilson. 2012. "Panduan Perilaku Pelanggan”. Penerbit PT. Gramedia Pustaka Utama. Jakarta.

Sugiyono. 2014. "Metode Penelitian Kuantitatif Kualitatif dan $R$ \& $D$ ". Penerbit CV. Alfabeta. Bandung.

Swastha, Bashu dan T. Handoko. 2008. "Manajemen Pemasaran Moderen". BPFE. Yogyakarta.

Syofian Siregar. 2010. "Statistika Deskriptif Untuk Penelitian". PT. Raja Grafindo Persada. Jakarta.

Tjiptono, Fandy dan Gregorius Chandra. 2012. "Serivce Quality and Satisfiation". Edisi tiga. Andi. Jakarta.

Umar, Husen. 2013. "Riset Pemasaran Dan Perilaku Pelanggan”. PT. Gramedia Pustaka Utama. Jakarta.

Usmara. 2003. "Strategi Baru Manajemen Pemasaran". Amoro book. Yogyakarta.

Wiliam J. Stanton, 2010. "Prinsip-Prinsip Pemasaran”, Edisi ketujuh, Erlangga, Jakarta. 